\title{
Rates of Channel Erosion in Small Urban Streams ${ }^{1}$
}

\author{
By Derek B. Booth and Patricia C. Henshaw \\ Center for Urban Water Resources Management \\ Department of Civil Engineering \\ University of Washington
}

\begin{abstract}
We address four objectives, focused on urban and urbanizing watersheds that drain forested (or once-forested) landscapes in humid regions: to document rates of channel change, to evaluate the relationship between development intensity and the rate of channel change, to evaluate geologic and topographic controls on channel change, and to determine if predevelopment conditions can be used to predict erosion-susceptible reaches. We used an 11-year data set covering 21 urban and suburban channels in western Washington, draining watersheds from 0.1 to $20 \mathrm{~km}^{2}$, a range that covers both seasonal and perennial channels that generally respond readily and rapidly to watershed disturbance. The results indicate:

1. Rates of vertical channel change vary from below the range of measurement error ( $<20$ mm vertical change between visits) to about $1 \mathrm{~m}$ (width-averaged) per year. The median rate for this sample population was $60 \mathrm{~mm}$ per year.

2. Within these lightly to moderately urbanized watersheds, rates of channel change did not correlate with development intensity.

3. The nature of the geologic substrate strongly influenced whether or not significant channel change occurred, but no unconsolidated substrate appears immune to change given sufficiently severe watershed disturbance. Erosion rates are independent of channel gradient within the range investigated (0.013-0.52).

4. Channels with the greatest susceptibility to rapid vertical change share the following characteristics, which can be used to predict and so reduce the consequences of future urban development on natural stream systems:

- Erosion-susceptible geologic substrate;

- Moderate to high gradient;

- Absence of natural or artificial grade controls;

- Predevelopment runoff inputs predominantly via subsurface discharge, likely to be converted to surface (point) discharge in the post-development condition.
\end{abstract}

\section{INTRODUCTION}

Changes to channel morphology are among the most common and readily visible effects of urban development on natural stream systems in humid environments. The actions of deforestation, channelization, and paving of the uplands can produce tremendous changes in the delivery of water and sediment into the channel network. In channel reaches that are alluvial, subsequent responses can be rapid, dramatic, and readily documented. Channels widen, deepen, and in extreme cases may incise many meters below the original level of their beds. Alternatively, they may fill with sediment derived from farther upstream and braid into multiple rivulets threading between gravel bars. In either case, they become aesthetic eyesores and biological invalids; natural populations of benthic invertebrates and fish are decimated, to be replaced by limited numbers and taxa of disturbance-tolerant species.

This chapter reviews the current understanding of the behavior and physical changes reported from stream channels in urban and urbanizing watersheds. Our focus is on those draining forested, or once-forested, landscapes in humid regions because the subsequent channel changes there appear to be most dramatic and detrimental to physical, biological, and aesthetic attributes. The historic data on channel changes is supplemented by our own 11-year data set on urban and suburban channels in western Washington, draining watersheds from 0.1 to $20 \mathrm{~km}^{2}$, a range that covers both seasonal and perennial channels that generally respond readily and rapidly to watershed disturbance.

1 D.B. Booth and P.C. Henshaw, 2001, Rates of channel erosion in small urban streams: chapter in M. Wigmosta and S. Burges, eds., Land Use and Watersheds: Human Influence on Hydrology and Geomorphology in Urban and Forest Areas: AGU Monograph Series, Water Science and Application Volume 2, pp. 17-38. 


\section{Previous Studies}

Although urban-induced channel changes are widely recognized, their magnitudes, rates, and controls are largely matters of sparse data and anecdotal information. As a result, we have only limited understanding of the physical determinants of channel change and even less predictive ability of the likely consequences of urban development on downstream channels. Although a variety of papers have explored the phenomenon of channel change in urban environments, they do not establish a consistent framework because they have analyzed the process from multiple perspectives:

- Watershed hydrology, where the most detailed analysis is conducted on the hydrologic changes brought by urbanization, and any channel response is shown or presumed to follow those changes directly;

- Sediment loading, where the delivery of sediment into the channel from an urban or urbanizing watershed is analyzed most completely, and the observed channel response is explained in whole or part through the trends of that sediment delivery over time; or

- Conceptual models of channel erosion and sedimentation, where a sequence of channel responses, initiated by watershed change, follows a predictable path somewhat independent of the details of the initiating upstream activity.

Watershed Hydrology. Changes in the hydrologic response of an urban watershed, notably the increase in stream-flow discharges, are demonstrably the clearest single determinant of urban channel change. Even where the channel is physically isolated from both physical disturbance and new inputs of coarse sediment, the occurrence and magnitude of increased discharges generally are mirrored by observed increases in channel dimensions. Previous studies that present such relationships include Hammer [1972], Hollis and Luckett [1976], Morisawa and LaFlure [1982], Neller [1988], Whitlow and Gregory [1989], Moscrip and Montgomery [1997], and Booth and Jackson [1997]. Yet this relationship, although common and intuitive, is not universal. A few studies note a reduction in channel width or depth with increases in watershed urbanization and, presumably, the discharge that accompanies it [e.g., Leopold, 1973; Nanson and Young, 1981; Ebisemiju, 1989a; Odemerho, 1992].

Sediment Loading. Delivery of sediment into the channel network is a common consequence of urban development with potentially significant expression in the channel form. The broad relationship between stages of watershed development and resulting sediment loads have been presented in studies such as Wolman [1967], Graf [1975], and Douglas [1985; Table 1, below]. Increased sediment loads, generated at particular stages in the forest-agriculture-urban sequence of North American land development, exert an opposing tendency on the channel to that of increasing discharge and probably explain much of the channel narrowing or shallowing that is sometimes measured.

TABLE 1. Conceptual relationship between stages of development, sediment yield, and channel stability [from Douglas, 1985].

\begin{tabular}{|c|c|c|c|c|}
\hline "Stage" & Land Use & Lag time & Sediment Yield & Channel Stability \\
\hline A & $\begin{array}{l}\text { Natural forest or } \\
\text { grassland }\end{array}$ & 100 years & low & $\begin{array}{l}\text { Relatively stable with some } \\
\text { bank erosion }\end{array}$ \\
\hline B & Heavily grazed & 80 & low to moderate & Somewhat less stable \\
\hline $\mathrm{C}$ & Cropping & 75 & moderate to heavy & $\begin{array}{l}\text { Some aggradation and } \\
\text { increased bank erosion }\end{array}$ \\
\hline $\mathrm{D}$ & $\begin{array}{l}\text { Abandonment of } \\
\text { cropping; } \\
\text { permanent grass }\end{array}$ & 85 & low to moderate & Increased stability \\
\hline $\mathrm{E}$ & Urban construction & 40 & very heavy & $\begin{array}{l}\text { Rapid aggradation and some } \\
\text { bank erosion (can braid) }\end{array}$ \\
\hline $\mathrm{F}$ & Stabilization & 25 & moderate & $\begin{array}{l}\text { Degradation and severe } \\
\text { bank erosion }\end{array}$ \\
\hline G & Stable urban & 15 & low to moderate & Relatively stable \\
\hline
\end{tabular}

Conceptual Models of Channel Erosion and Sedimentation. Previous efforts to integrate the generally similar, but locally disparate, observations of channel change [see Park 1997] into a unified model generally articulate a sequence of anticipated changes over time. For example, Douglas [1985] suggested a specific pattern of watershed development and channel response (Table 1$)$. 
Simon [1989] evaluated the consequences of channelization and described a predictable evolutionary sequence of undercutting, bank failure, channel widening, and restabilization that closely resembles that of urbanization. Arnold et al. [1982] also recognized the interplay of spatial factors, notably upstream stream erosion and downstream deposition, that can result in multiple "responses" along the same channel, a theme of complex spatial and temporal response echoed by Gregory et al. [1992] and Park [1997].

\section{Lessons from Previous Work}

In any given locality, observed correlations between channel size, rate of channel change, and watershed characteristics are likely to be fortuitous or at least non-universal. In general, the dimensions of channels in an urban stream network will tend to follow the overall pattern of discharge across that network-larger flows beget larger channels. Consequently, a naïve prediction of channel change based on the magnitude of anticipated hydrologic change [Booth, 1991] is also probably justified as a first-order estimate (e.g., Figure 1 as an example from the Pacific Northwest). Yet details of the channel, the watershed, and the timing and location of the measurement itself may overwhelm this presumption of channel-discharge equilibrium for the following reasons:

- Location of the measurement station in the channel network: Is the measurement located in a "transport" reach, where water and sediment are passed downstream with little channel adjustment, or a "response" reach, where channel form readily adjusts to changing conditions? Not every channel responds to increasing sediment load or water discharge in the same way [e.g., Montgomery and Buffington, 1997]. Local channel gradient and the pattern of gradient changes across a channel network are particularly important factors, but they are rarely reported or incorporated into case-study analyses.

- Location of urban development relative to the channel network: This includes the obvious factors that headwater development will affect more of the channel network than one that drains into the stream farther downstream, and that the influence of a particular area of disturbance will be proportionally greater on progressively smaller catchments. Similarly, developments that concentrate urban effects in only a few areas tend to have less impact on the channel network as a whole than equivalent development spread across the watershed [Ebisemiju, 1989b]. In addition, flow increases introduced at one point in the channel network may be far more effective at eroding sediment than at another, because of the spatial variability of watershed soils and the distribution of alluvial and bedrock (or other nonalluvial) reaches.

- Interplay of the timing of watershed development, large storms, and stream-channel observations: Many of the "relationships" advocated in the literature between channel form and the magnitude and age of the watershed development are probably artifacts of a particular combination of unique temporal or geomorphic factors [Henshaw, 1999]. "Stable" stream channels may simply reflect a lack of recent rainfall [e.g., Bird, 1982]. They are expected in mature systems where fluvial equilibrium has truly been reestablished (as anticipated for example by Hammer 1972, Neller 1988, Ebisemiju 1989b]; but alternatively, they may simply be the product of flushing all mobile sediment from the system to produce a relatively static, non-alluvial channel, where change may still occur [e.g. Tinkler and Parish, 1998] but at rates generally slower than reported elsewhere. If equilibrium can be achieved in a disturbed fluvial system, it will depend not only on the at-a-station fluvial processes but also on factors outside of, and perhaps wholly unaccounted by, fluvial conditions in the immediate channel reach. These factors include adjacent hillslope stability, which may have a dramatically longer time scale for stabilization than the fluvial system; and channel stability farther upstream, particularly the absence of large upstream sediment sources.

Most previous studies have reported examples of particularly dramatic channel changes. These sites are commonly erosional, because this response is generally more rapid and more localized than deposition, and because the occurrence of channel erosion (particularly downcutting, commonly the first such fluvial response) can initiate adjacent hillslope failures that mobilize substantially more sediment over a wider area than the original fluvial process. Thus they call attention to themselves from researchers and the public alike. That attention is entirely appropriate- such changes are among the most serious environmental disruptions for both human and biological use of streams in the urban environment. However, such a level of attention introduces a bias into our assessment of what constitutes "urban channel changes." 


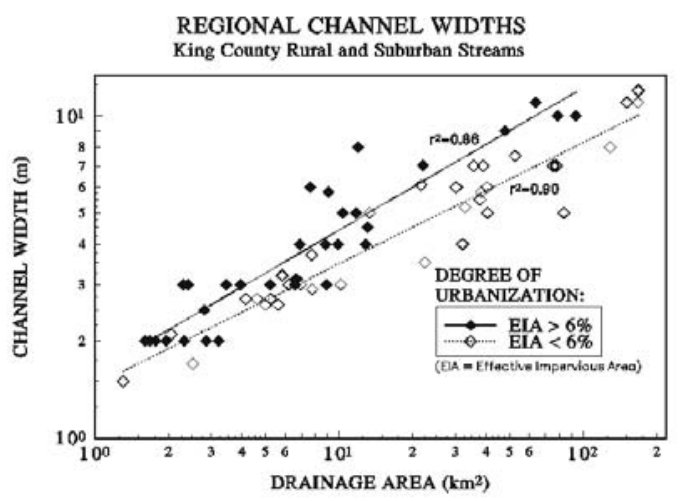

Figure 1. Bankfull channel widths, segregated by percent effective impervious area (EIA; see Dinicola, 1990) contributing to the measurement point. A discrimination at 6 percent EIA was chosen because it approximates the rural-to-suburban transitional land use in this region. From Booth and Jackson [1997].

\section{Channel Types and Classification}

Principles and Limitations. Geomorphologists and biologists have been organizing and categorizing the myriad array of stream channels for about a century. The purpose of such an organization is fundamental: if a channel of interest can be placed in a group, and the properties of that group are already known, then the properties of the new channel will also be known with little additional work [Kondolf, 1995]. Those "properties" depend on the organizational scheme, but they include such attributes as the channel's response to environmental change (such as increased sediment load or placement of an artificial habitat-enhancement structure) or its importance in supporting stream biota [Mosley, 1987]. Intrinsic differences between channels will strongly influence channel response to urban development.

Yet the influence of a classification scheme can be detrimental, by suggesting an overly simplistic range of channel conditions that obscures critical differences between channels that are ostensibly "the same." It may also impart a false understanding if the classification method is taken outside of where it was developed to where the dominant landscape processes, or range of landscape conditions, are significantly different: channels may be "classified" but the predictive power of that classification will be low or misleading.

Two examples, both relevant to urban stream channels of the Pacific Northwest, illustrate this problem. The classification method of Rosgen (e.g., 1994 and prior informal publications), applied widely throughout the United States, does not include the influence of large logs and other woody debris on channel processes, reflecting the non-forested environment in which this method was first developed. A forested stream may be "classified" by this method but the nature of its response to human disturbance may be poorly predicted. In contrast, the classification of Montgomery and Buffington [1997] was established explicitly to address the channels found in forested watersheds of the Pacific Northwest, where such large woody debris (LWD) is ubiquitous and its influence can be dominant. Yet this method was developed in mountain drainage basins sharing a typical downstream progression from steep headwater catchments underlain by bedrock to gentler, larger watershed areas in broad alluvial valleys. This orderly sequence may not be matched in a lowland setting - the smallest watersheds of urbanizing Puget Sound can be quite flat, with steeper reaches located some distance farther downstream. Sediment-delivery processes and sources of channel roughness are very different in lowland urban channels than in nearby mountainous channels, and so this classification system also may not fully predict the response of a particular urban stream.

Criteria. Despite these caveats, different channel "types" display different intrinsic channel behaviors and have different responses to watershed disturbance. No framework has been fully developed for our environment of interest, but we are using the conceptual approach of Montgomery and Buffington [1997] because of its orientation on channel-forming processes, its development in the same climatic region as the present study, and its explicit recognition of the influence of LWD and other such obstructions on channel morphology. By their terminology, most of our channels are either "planebed" or "forced pool-riffle" channels—relatively flat-bottomed channels lacking well-defined bedforms and instead displaying long, and commonly channel-wide, reaches of uniform riffles or glides which can aggrade or degrade rapidly in response to changing water and sediment fluxes. Development of a more heterogeneous morphology depends on the presence of immobile material, most commonly LWD. By restricting our evaluation to such channels, we may be limiting the potential utility of our work. Yet the vast majority of the small, responsive, urban streams in our region fit these categories, and this selectivity helps avoid the risk of transferring results inappropriately. 


\section{A Conceptual Framework to Assess Channel Change in Urban Watersheds}

Past studies and repeated observation suggest a "typical" scenario for channel change in an urbanizing lowland watershed. Recognizing that this scenario does not encompass the full range of potential watershed conditions or streamchannel responses, it nonetheless characterizes the most common "problems" of urban channel change and highlights those settings where an unexpected response suggests the presence of atypical channel or watershed conditions.

Consider a watershed of some tens of hectares up to several square kilometers, where development has blanketed the upper watershed and so the first-order channel(s) are the most fully affected of any in the channel network. In most cases, channel expansion of at least several times the original cross sectional area accompanies the progression from rural to suburban to urban land uses. Whether or not the response of the channel to these flow increases is "orderly" (i.e. channelsize increases in approximate proportion to discharge increases in the sense of Booth, 1990) or "catastrophic" (i.e. rapid incision) is largely independent of the magnitude of the watershed disturbance (see below). Even low levels of land-cover changes, if accompanied by an efficient collection system (e.g., road ditches) can produce significant increases in headwater channel discharges, which in turn will initiate increased in-channel erosion and sediment transport.

Because such land-use changes typically occur over a period of many years or decades, they tend to produce continuous changes in the downstream channel subject only to the variability of seasonal runoff. Any tendency towards "equilibrium," either dynamic or static, is completely obscured during this period. Sparse long-term data suggest that true equilibrium may be possible in watersheds with constant land use, over a years-to-decades time lag [Henshaw, 1999], but actually observing such a condition depends on achieving stable hillslope conditions as well, which may take many times longer. With these complications, it is not surprising that "reequilibration" may be more useful as a theoretical construct than as a widely observed condition.

The sediment released by this scenario of headwater flow increases may or may not accumulate as it passes through the downstream channel network. The potential input of additional urban-flow-induced sediment from other lateral tributaries will combine to influence whether sediment, eroded from upstream reaches, can remain in active transport or will accumulate in noteworthy volumes. Curiously, the vagaries of human infrastructure, particularly small roadway culverts that were sized and installed during an earlier pre-headwater-development era when only lower discharges of water (and tremendously lower discharges of sediment) occurred, appear to be one of the strongest single determinants of whether the urban channel change is perceived to be mainly a problem of “erosion” or one of “deposition” (Figure 2).

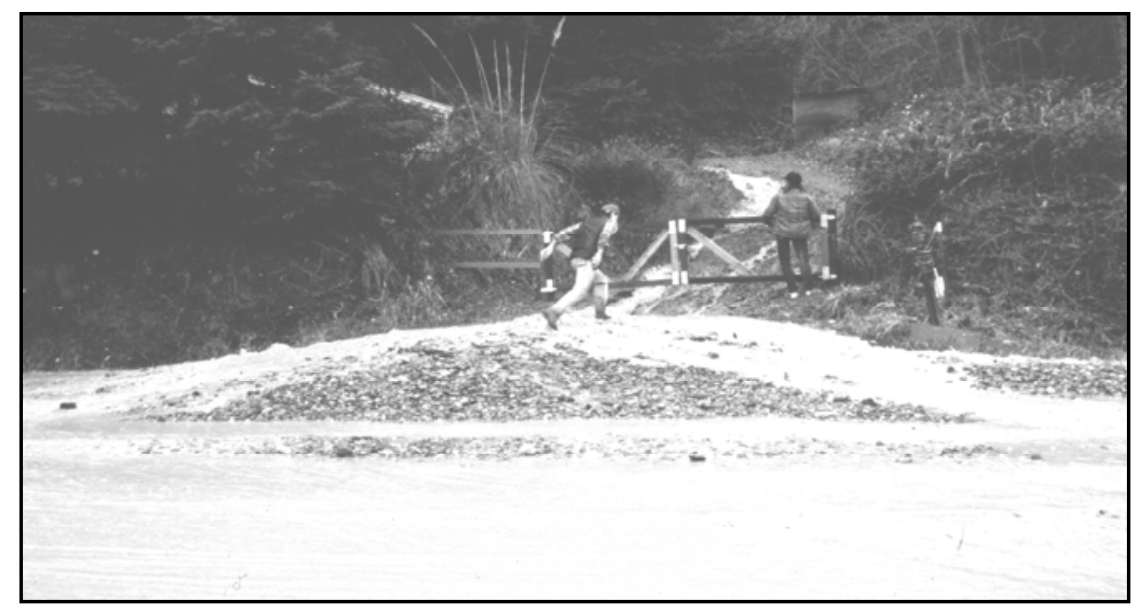

Figure 2. Deposition of stream-channel sediment, eroded from upslope reaches of tributary 0143G (station C8). 


\section{FIELD INVESTIGATIONS}

No single study can cover all settings in which urban-induced channel change is observed. Yet even a geographically limited set of new data can increase our understanding and prediction of this threat to aquatic-system integrity. This study was initiated to provide some of that new data, focused on a part of western Washington state where (and beginning at a time when) the rate of new urban development was accelerating to historically unprecedented rates. It also began when the social and political desire to alleviate the worst environmental consequences of that development far exceeded the concrete knowledge necessary to achieve that goal.

Starting in 1986, 35 stations along an equal number of independent streams were established to monitor long-term channel changes in urbanizing watersheds. The purpose of this effort was four-fold:

1. To document erosion and deposition rates in a variety of physiographic settings;

2. To test the hypothesis that urban development consistently increases the rate of channel change, and that higher levels of urban development are correlated with faster rates of channel change;

3. To test the hypothesis that certain geologic and/or topographic settings are particularly susceptible to urbaninduced channel changes; and

4. To improve identification of the most susceptible sites before development, and thus before degradation, has begun.

\section{Methods}

Study sites. The choice of channel reaches for monitoring began in early 1986, following a particularly large storm in January that resulted in many instances of channel modification and property damage from high discharges. These first sites were chosen because of known stream-channel erosion, reported downstream problems, or knowledge of impending development that might prove problematic. Over the next several years, a number of additional sites were identified and some unsuitable sites were relocated or abandoned, mainly due to unrepresentative channel conditions but also because of subsequent obliteration by development activity. A range of channel conditions, particularly slope, degree of upstream development, and geographic location, were covered by the final set of 21 selected sites (see Figures 3 and 4 and Table 2). Previous observations had suggested that channel changes were particularly rapid downstream of recent urban development in small headwater catchments and in channels traversing hillslope deposits of a specific regionally common geologic deposit, so these characteristics were emphasized in the initial site selection. 
TABLE 2. Stream erosion station characteristics.

\begin{tabular}{|c|c|c|c|c|c|c|c|}
\hline Station & Station Name & $\begin{array}{l}\text { Drainage } \\
\text { Area } \\
\left(\mathrm{km}^{2}\right)\end{array}$ & $\begin{array}{l}\text { Local } \\
\text { Slope } \\
\%\end{array}$ & $\begin{array}{l}\% \\
\text { EIA }^{1}\end{array}$ & $\begin{array}{l}\text { Channel } \\
\text { Width } \\
\text { (m) }\end{array}$ & $\begin{array}{l}\text { Substrate } \\
\text { Type }\end{array}$ & $\begin{array}{l}\text { Length } \\
\text { of } \\
\text { Record } \\
\text { (yrs) }\end{array}$ \\
\hline $\mathrm{C} 1$ & McAleer Creek & 18 & 2 & 22 & 9.8 & silt-clay & 7 \\
\hline C2 & $\begin{array}{l}\text { McAleer } \\
\text { tributary }\end{array}$ & 0.6 & 2 & 20 & 4.1 & silt-clay & 11 \\
\hline C3 & $\begin{array}{l}\text { Holmes Point } \\
\text { trib. }\end{array}$ & 0.5 & 5 & 16 & 2.4 & sand & 4 \\
\hline C4 & $\begin{array}{l}\text { Juanita Point } \\
\text { trib. }\end{array}$ & 0.4 & 4 & 12 & 1.7 & sand & 11 \\
\hline C6 & $\begin{array}{l}\text { Skookum } \\
\text { tributary }\end{array}$ & 1.7 & 2 & 5 & 2.5 & sand & 9 \\
\hline C7 & $\begin{array}{l}\text { Timberline trib. } \\
\text { 0143F }\end{array}$ & 0.2 & 14 & 1 & 2.3 & sand & 7 \\
\hline C8 & $\begin{array}{l}\text { Timberline trib. } \\
\text { 0143G }\end{array}$ & 0.1 & 48 & 15 & 2.3 & sand & 11 \\
\hline C9 & upper 0164A & 0.5 & 3 & 16 & 4.9 & sand & 7 \\
\hline C11 & Ginger Creek & 1.8 & 5 & 22 & 7.9 & sand & 5 \\
\hline C12 & $\begin{array}{l}\text { mid-Madsen } \\
\text { Creek }\end{array}$ & 6.5 & 3.5 & 10 & 6.6 & sand & 10 \\
\hline C13 & $\begin{array}{l}\text { Hollyw'd Hills } \\
\text { trib. }\end{array}$ & 4 & 2 & 7 & 4.6 & sand & 7 \\
\hline G2 & Garrison Creek & 2.6 & 5 & 10 & 1.8 & sand & 2 \\
\hline G3 & Mill Creek & 4 & 2.8 & 19 & 4.3 & sand & 3 \\
\hline G5 & Cobble Creek & 0.7 & 5.5 & 11 & 4.8 & silt-clay & 11 \\
\hline PS3 & $\begin{array}{l}\text { Easter Lake } \\
\text { outlet }\end{array}$ & 0.6 & 1.3 & 40 & 3.7 & sand & 11 \\
\hline PS4 & $\begin{array}{l}\text { Olympic View } \\
\text { Park }\end{array}$ & 1.5 & 2.1 & 17 & 2.4 & sand & 11 \\
\hline PS7 & Boeing Creek & 5 & 2 & 20 & 8 & sand & 2 \\
\hline S2 & $\begin{array}{l}\text { Chasm Creek } \\
\text { mainstem }\end{array}$ & 0.2 & 5 & 3 & 2.4 & sand & 4 \\
\hline S3 & Pepper Creek & 1 & 5 & 5 & 6.6 & sand & 7 \\
\hline S4 & $\begin{array}{l}\text { Lk. Alice Estates } \\
\text { trib. }\end{array}$ & 0.1 & 52 & 10 & 2.6 & sand & 11 \\
\hline S5 & $\begin{array}{l}\text { Joule short plat } \\
\text { trib. }\end{array}$ & 0.1 & 5 & 5 & 2.4 & sand & 4 \\
\hline
\end{tabular}

${ }^{1}$ EIA = Effective impervious area

Most of the sites were, broadly speaking, alluvial channels [Leopold et al., 1964]: carved by running water into the very sediment carried by that flow in the past, and that presumably could be carried by that flow in the future. These "selfformed" channels are free to adjust their shape in response to subsequent changes in flow and thus were anticipated to respond most sensitively to future development. However, as the channel changes in response to increased flows (and particularly if it begins to incise) the underlying hillslope deposit becomes more dominant as the channel-bounding sediment and the alluvial "character" of the channel can be reduced. In contrast, a channel formed in alluvial sediment but also choked with immovable roughness elements, such as logs, is not strictly "alluvial." Yet if those logs are removed, or if progressive bed erosion strands those logs above the elevation of the flow, the channel will become more characteristically alluvial over time.

The sample population was chosen to explore the influence of the underlying geology by emphasizing sites located on a particularly erodible substrate. Most of the stations have as their underlying substrate a thick and widespread sandy deposit with local concentrations of pebble to cobble gravel, laid down by glacial outwash streams during the last advance of the continental ice sheet (regionally named the "Vashon" by Armstrong and others [1965] and spanning an interval of 
about 17,000-13,000 years ago). This emphasis was established to quantify rates in what previously had been observed locally to be the most erosion-susceptible deposit. A moderate number of sites with other substrates were also included to test this hypothesis more precisely.

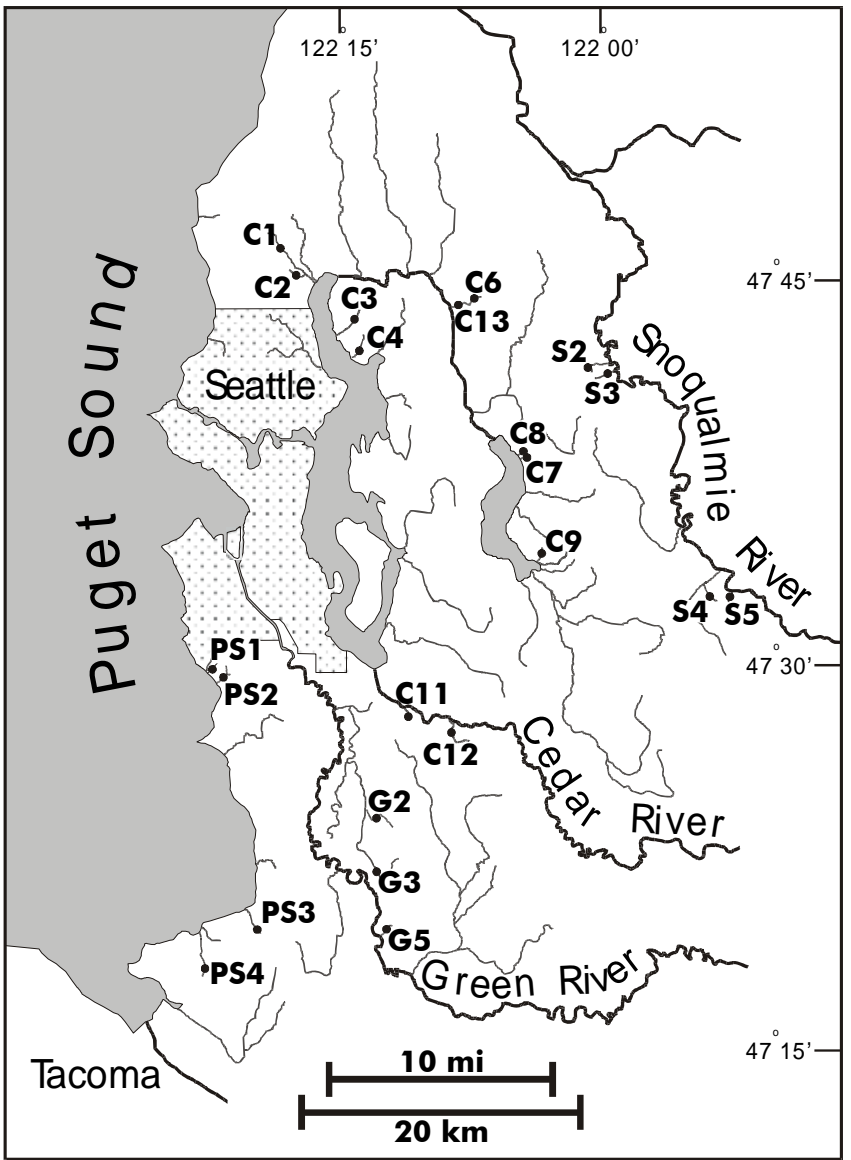

Figure 3. Location of stream measurement stations listed in Table 2.

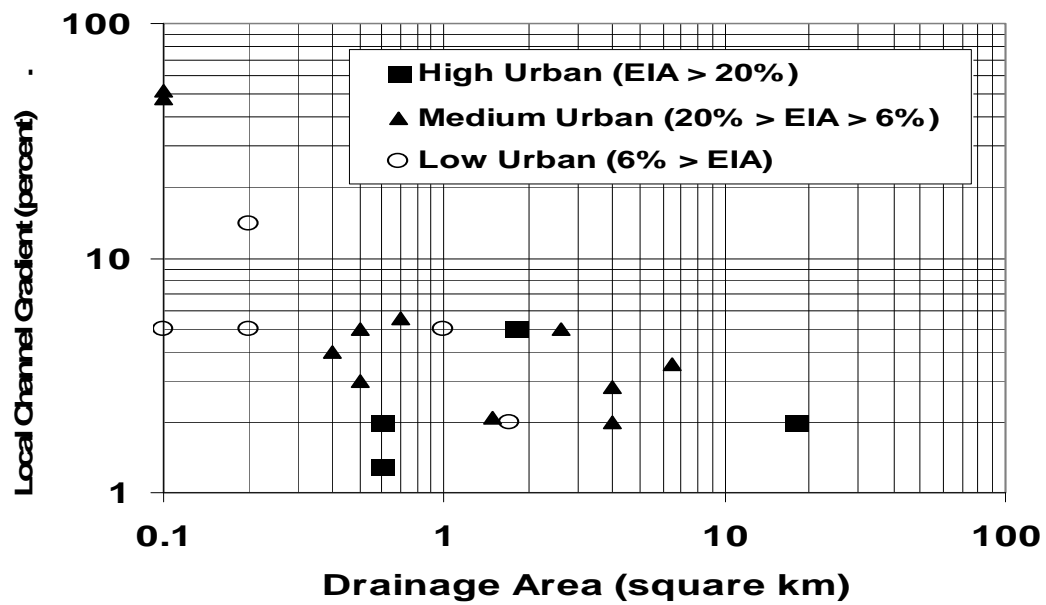

Figure 4. Summary attributes of measurement stations listed in Table 2. 
The work was initially sponsored by the jurisdiction of King County, Washington, so all sites were located within its boundaries. By virtue of its location and size, however, this 5000-square-kilometer area cuts a remarkably diverse and representative swath across the Puget Lowland and Cascade Range of western Washington; it also spans a range of land uses from forested wilderness through agriculture, suburbia, and intensely urban. In the rapidly developing suburban fringe targeted by this study, annual precipitation averages about $1000 \mathrm{~mm}$, falling primarily from October to April as large frontal storms of several days' duration. Unlike much of the rest of the continent, short but intense storms are rare. The 100-year 6-hour rainfall intensity in this region is only about $5 \mathrm{~mm} / \mathrm{hr}$ [Miller et al., 1973], whereas the largest stream discharges are generally associated with moderate-intensity rainfall following a period of extended wintertime precipitation or snowmelt.

Measurement Techniques. Cross sections were measured using two procedures, modified from that suggested in Dunne and Leopold [1978]. A specific location along a relatively straight and uniform part of the channel, qualitatively judged to be "representative" of the reach in question, was selected. Two endpoints were established to define a line approximately perpendicular to the channel. Where available, streamside trees were used and the precise endpoint was marked with a $12 \mathrm{~d}$ galvanized nail driven nearly flush with the trunk. Where trees were unavailable, 0.6-meter-long pieces of reinforcing bar ("1/2-inch rebar") were driven into the ground to provide a suitable monument. We rarely had much difficulty in relocating such markers, even after four years’ absence, with sufficiently detailed notes.

In the early years of this study, a 50-m steel tape was stretched and held at constant tension between endpoints to provide both horizontal and vertical reference. The vertical distance between the tape and the ground surface was recorded at 0.3-m intervals, together with additional intermediate measurements at marked breaks in slope. At each station, the vertical angle and the parabolic sag of the tape were measured and used to correct the raw data. This method had the advantage of speed and minimal field equipment but had some inherent inaccuracies. In the last year of the study we used an automatic level and surveyor's rod to determine channel depths, relying on the stretched tape only to specify horizontal distance. By direct comparison of these two measurement methods, we could determine the precision of the early method; its error was consistently less than $0.02 \mathrm{~m}$, at or below the degree of inescapable measurement imprecision imposed by ground irregularities and sediment clasts on the channel bed.

In the early years of the project, measurements at most sites were made annually in the summer, the season when qualitative observations suggest that little or no channel changes occur from about June until October. After collecting data in the summer of 1990 from changes during the large storms of January 1990, the primary objectives of the study had been achieved and measurement frequency was reduced, with visits to most sites only in 1993 and 1997.

Results

Overview. Rates of erosion and deposition vary by over two orders of magnitude (see Figure 5). In this population, the minimum amount of the annual width-averaged vertical channel change was below the level of measurement error (about $20 \mathrm{~mm}$ ); the maximum was about $1 \mathrm{~m}$ per year. Over the 11-year period, 80 percent of all measurements show an annual width-averaged vertical change (erosion or deposition) of less than 0.2 meters, with the median of all measurements at 60 $\mathrm{mm} /$ year.

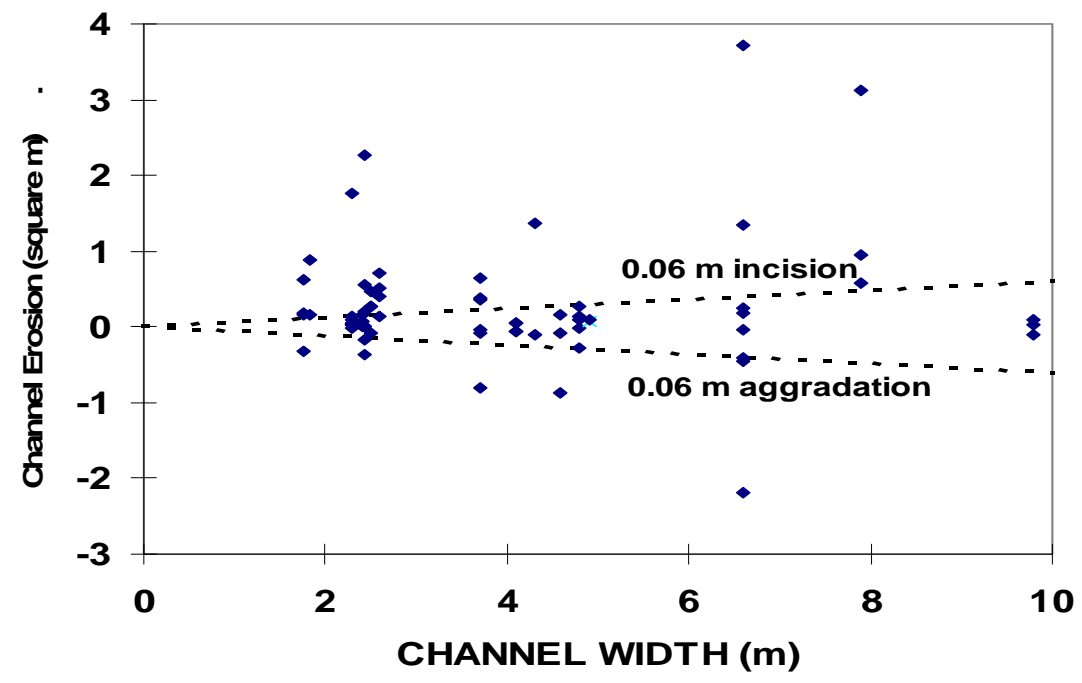

Figure 5. Results of all measurements, expressed as the average change in cross-section area per year between visits. Dotted lines plot the median vertical change of $0.06 \mathrm{~m}$. 
The most consistent pattern is the correlation of rainfall with channel change. This outcome is qualitatively intuitive, although the nature of this relationship is more complex than might be first anticipated. For example, 1990 channel changes (i.e. occurring between the 1989 and 1990 measurements) are the largest, by a significant degree, at nearly all sites (Figure 6). Although the 1990 rainfall intensities are also the largest in the period as well (Figure 7), they do not exceed other "large" years (1991 and 1996) by nearly as much as the erosion/deposition measurements would suggest.

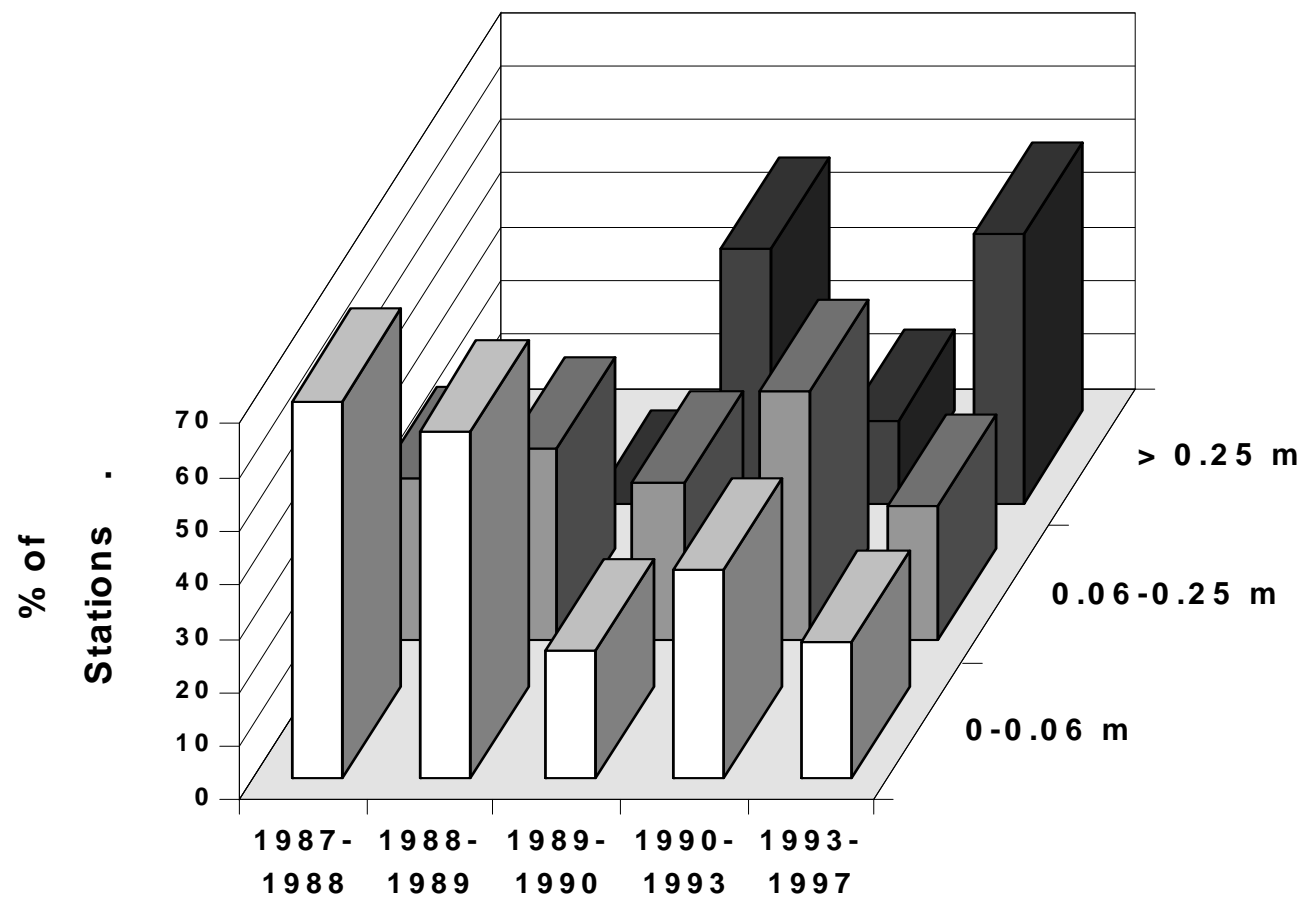

Figure 6. Distribution of stations below, above, and greatly above the median vertical change of $0.06 \mathrm{~m} / \mathrm{year}$. Channel changes are calculated across the full period between measurements and are not annual averages. Note that the distribution of stations in the 19891990 interval is nearly identical to that of 1993-1997, even thought the earlier period is only one-quarter as long.

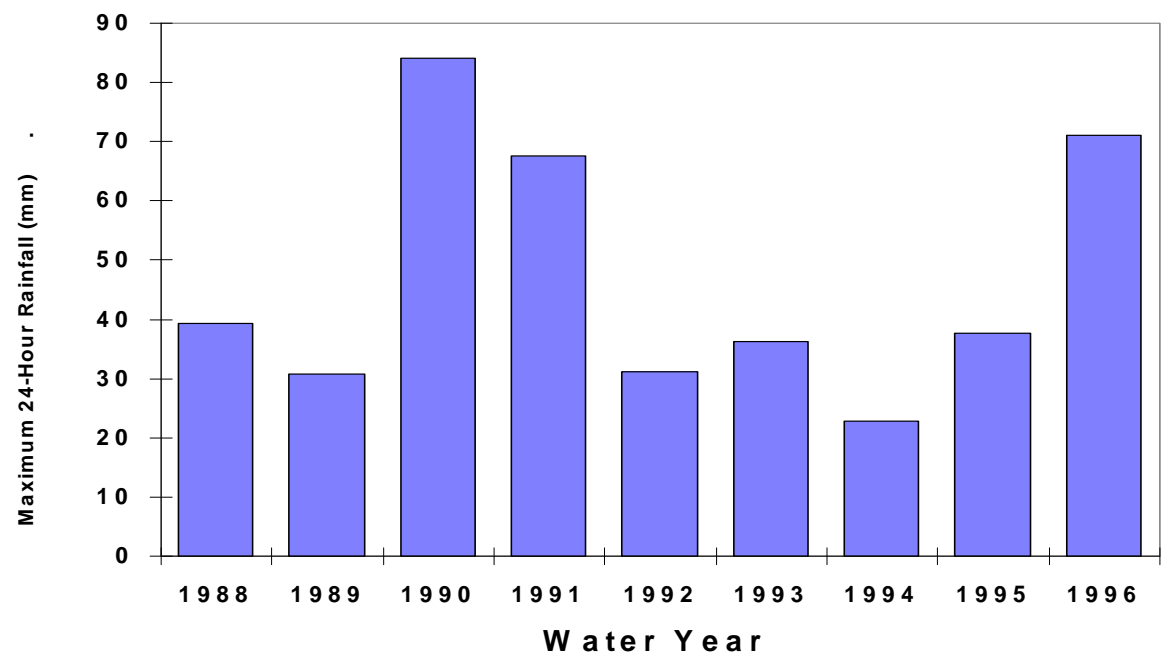

Figure 7. Maximum 24-hour rainfall for each year of the interval 1988-1996. The chosen gauge ("Maplewood") was centrally located for the study sites (near station C11 on Figure 3). 
Most noteworthy of this data set, however, is the overall absence of general relationships between measured channel changes and simple, physical parameters of the stream or of the watershed, such as slope (Figure 8) or imperviousness (Figure 9). This condition bodes poorly for the kinds of simple predictive methods favored by local governmental jurisdictions in the prediction and avoidance of environmental impacts. Only the role of geologic materials shows any consistency, with cohesive silt-clay substrates generally permitting only low rates of channel adjustment.

The poor correlation between effective impervious area (EIA) and channel change is quite robust. It is displayed by both the station averages for the period of record (Figure 9) and the single-year (1989-1990) data (Figure 10). We therefore reject the first of our initial hypotheses, that urban development consistently increases the rate of channel change, and that higher levels of urban development are correlated with faster rates of channel change.

Evidence against this hypothesis is particularly clear at the following stations, discussed below in greater detail:

- Moderate to high development, moderate to minimal changes:

* Easter Lake outlet (40\% EIA, moderate change)

* Olympic View Park (17\% EIA, very little change)

* McAleer Tributary (20\% EIA, very little change)

- $\quad$ Little development, large changes:

* Pepper Creek (3\% EIA, very large change)

Although hydrologic processes may impose a general tendency for increased urbanization to yield greater channel change, the expression of that change is completely swamped by the vagaries of local conditions.

Our other initial hypothesis, the association of particular topographic or geologic conditions with rate of change, finds much more consistent support from the data. Granular hillslope deposits, normally mantled by alluvium but accessible to streamflow in an incising environment, were anticipated to display the greatest changes for a given degree of upstream urbanization; indeed, a majority of sites were chosen on the basis of this very attribute. The type of deposit does appear to exert a significant influence on channel-change rates; the most common alternative, cohesive silt-clay deposits, consistently showed low or very low rates of change.

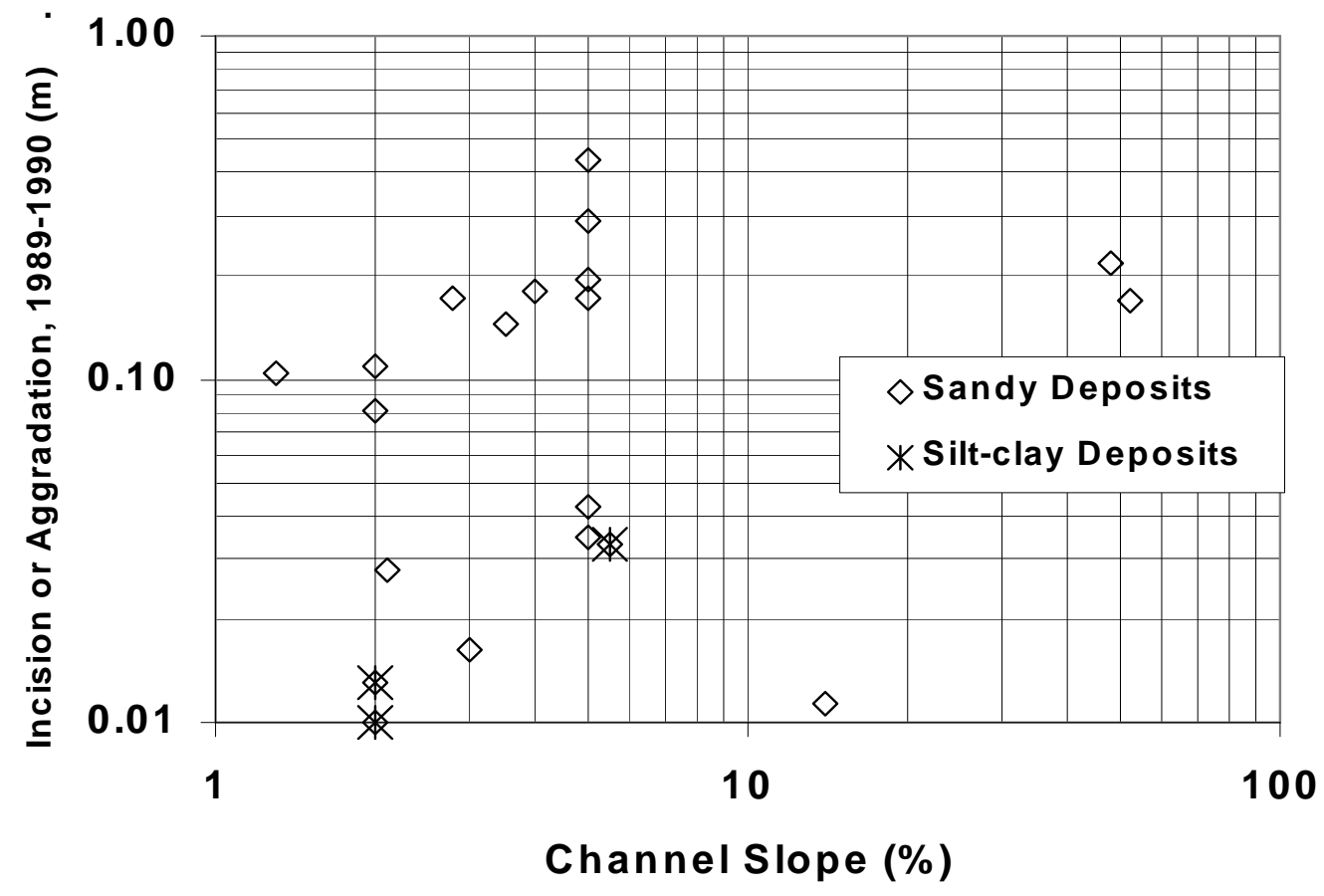

Figure 8. Demonstration of the poor correlation between local channel slope and the magnitude of one year's width-averaged vertical change. A more consistent pattern is suggested by the relatively low change shown at each of the three stations underlain by cohesive (silt and clay) hillslope deposits. 


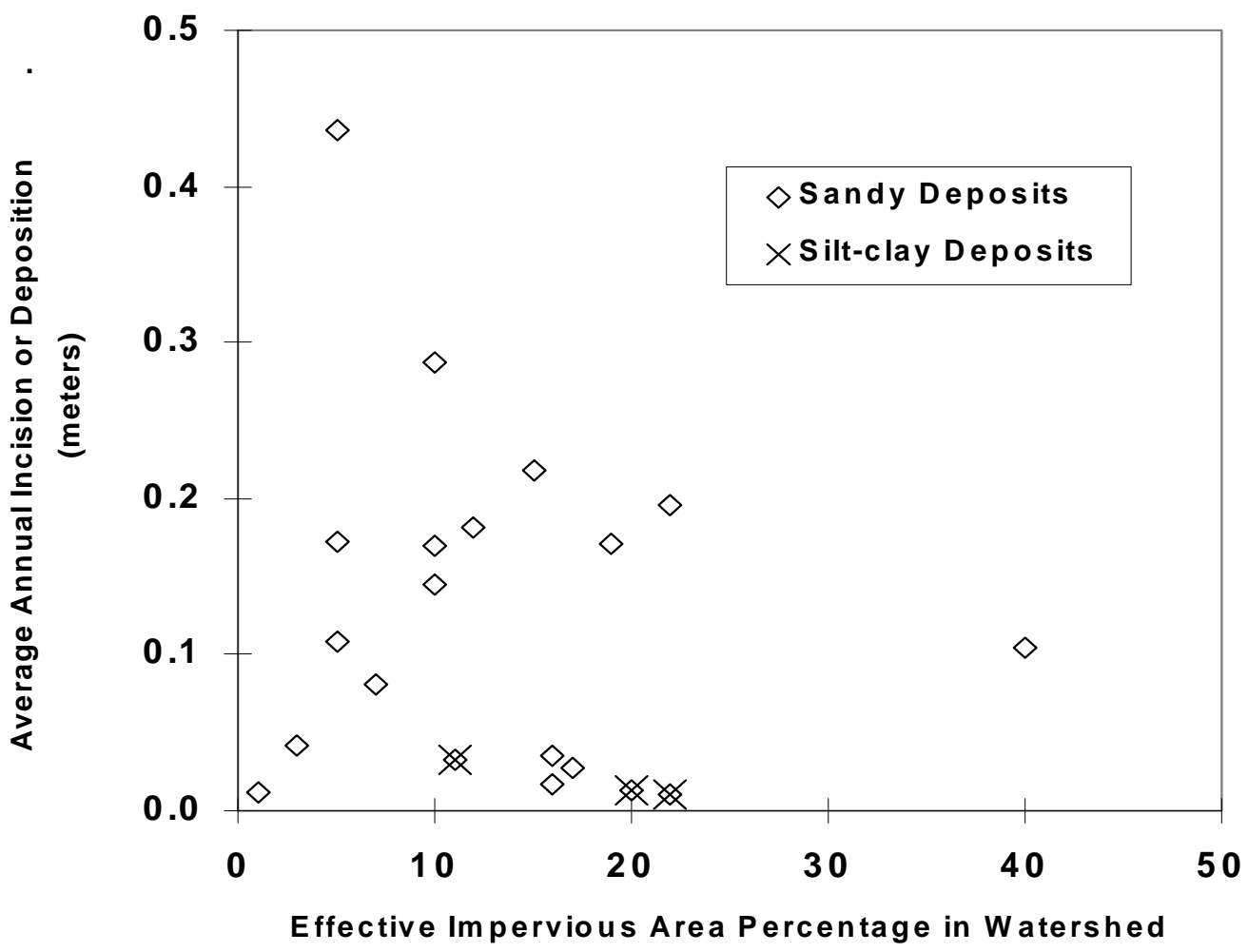

Figure 9. Demonstration of the poor correlation between contributing impervious area and the magnitude of the annual width-averaged vertical change, averaged over the full duration of each station's measurement history.

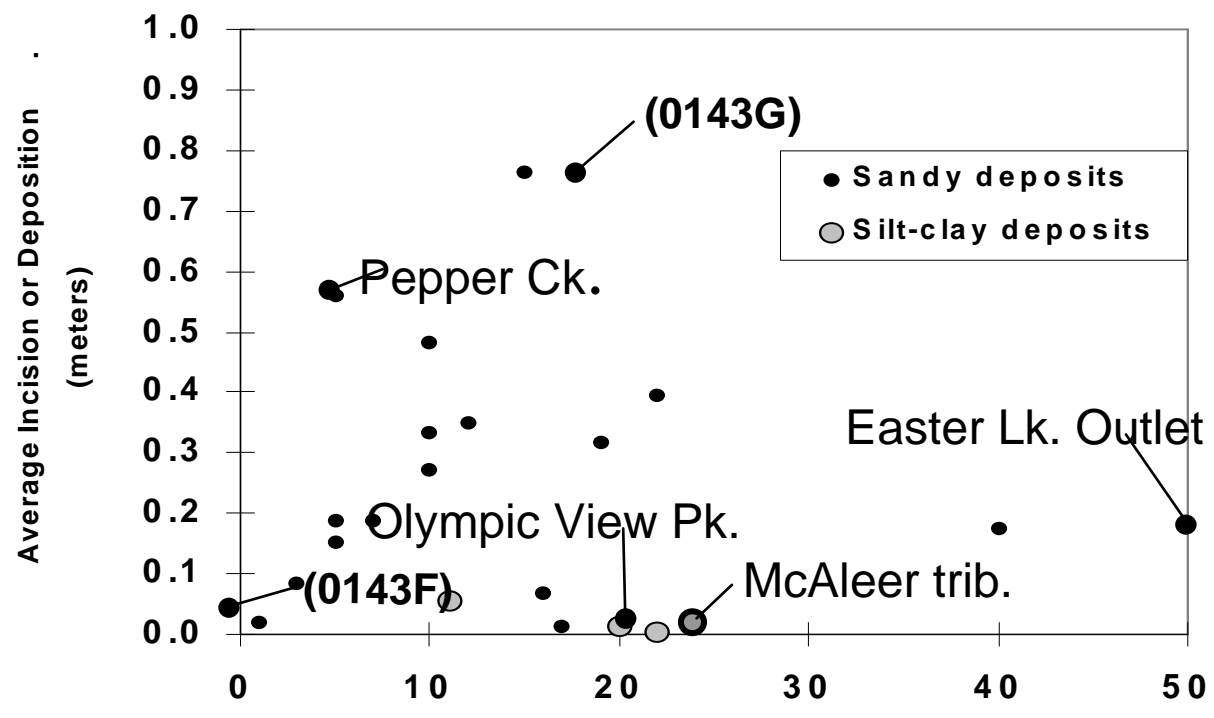

Effective Impervious Area Percentage in W atershed

Figure 10. The equivalent parameters as for Figure 9 but considering only the measurement interval with the greatest change, 1989-1990. There are no appreciable differences between the pattern expressed by either the single-year or the time-averaged results. Labeled points are discussed in the following section. 


\section{Specific Site Conditions (see Figure 10)}

Olympic View Park. This channel is located in a lightly developed parkland (Figure 11), established around the longprotected riparian corridor of the stream. The surrounding watershed has been almost fully developed for several decades, primarily with single-family residences. The ravine that contains the channel and associated park is excavated into deposits of the sandy Vashon advance outwash. Incision has clearly been part of the channel's past history; several hundred meters downstream of the measured cross section, large gabion baskets stabilize what must have been a major knickpoint in the 1970's. Yet the current decade of measurements is noteworthy in its near-negligible change from one year to the next (Figure 12), although the channel morphology is distinctly unappealing from either a biological or an aesthetic standpoint. It is relatively uniform, slightly sinuous, with virtually no heterogeneity or variability in size, shape, or roughness. Much of this uniformity is surely the result of close human contact - foot traffic up and down the channel (commonly dry in the summertime) is frequent, and any sticks or twigs would be promptly "cleaned up.” Yet even where encroaching riparian shrubs limit the immediate access of people, conditions are essentially unchanged.

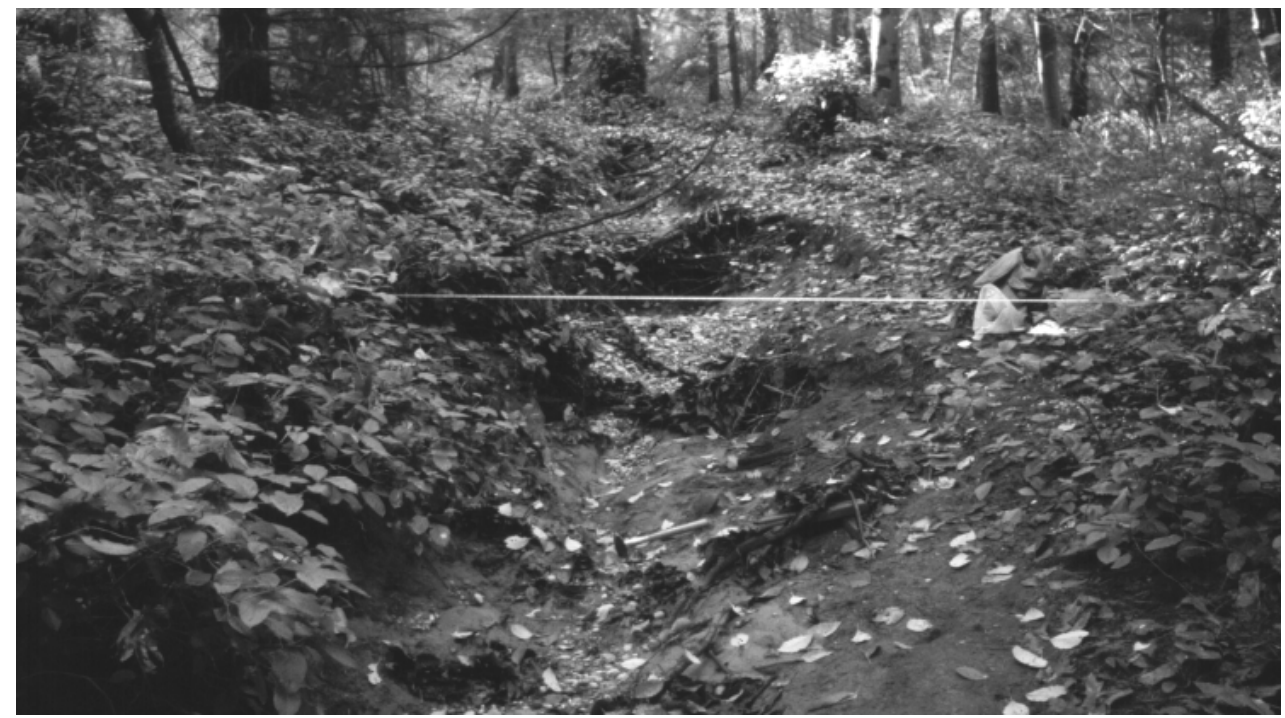

Figure 11. View of the channel of Olympic View Park (Station PS4) in 1986, looking upstream. Line across the channel (below the scale bar) is the tape measure used to determine horizontal distance at the cross section location.

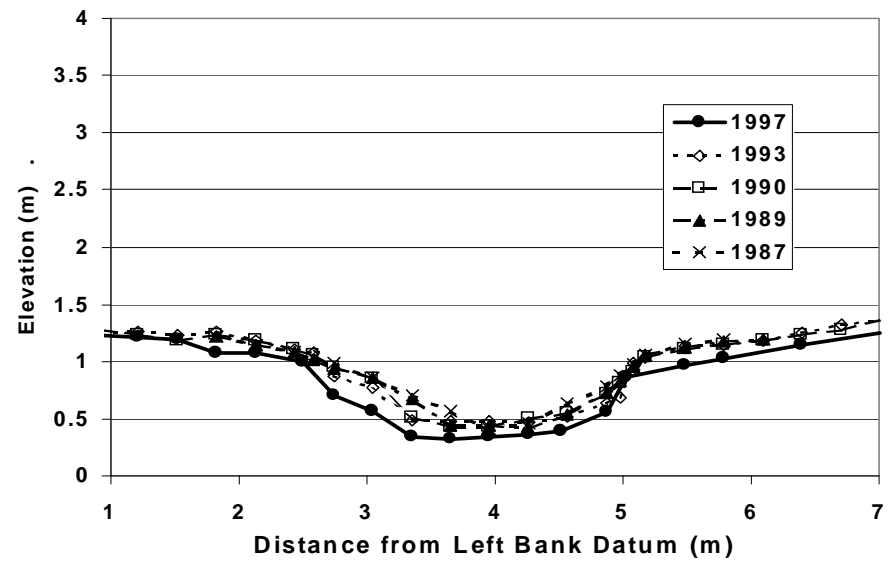

Figure 12. All cross section measurement of Station PS4, showing only minor changes from 1987 to 1993 (the total width-averaged erosion during this interval is $8 \mathrm{~cm}$ ) and from 1993 to 1997 (total average erosion $7 \mathrm{~cm}$ ). 
Easter Lake Outlet. This channel is also in a well-established part of King County, with a high level of urban development in the contributing watershed but with most of it predating 1970 . About 80 percent of the runoff from that watershed drains through Easter Lake, which occupies about 10 percent of the contributing surface area of the watershed and which provides significant hydraulic control of discharges. Continuous hydrologic modeling of this lake [King County, 1990] displays a marked reduction in the unit-area discharges here relative to other catchments without lakes in the immediate region.

The channel-measurement station lies within a reasonably well-protected riparian buffer, located entirely on private property and generally not accessed by nearby residents because of topography (Figure 13). The channel is incised about $1.5 \mathrm{~m}$ into a narrow upland terrace, probably the old floodplain, set within a broader valley. A complex of logs and a large tree root, about $20 \mathrm{~m}$ downstream of the section, have formed the lip of a 1-m knickpoint and probably have inhibited more dramatic degradation.

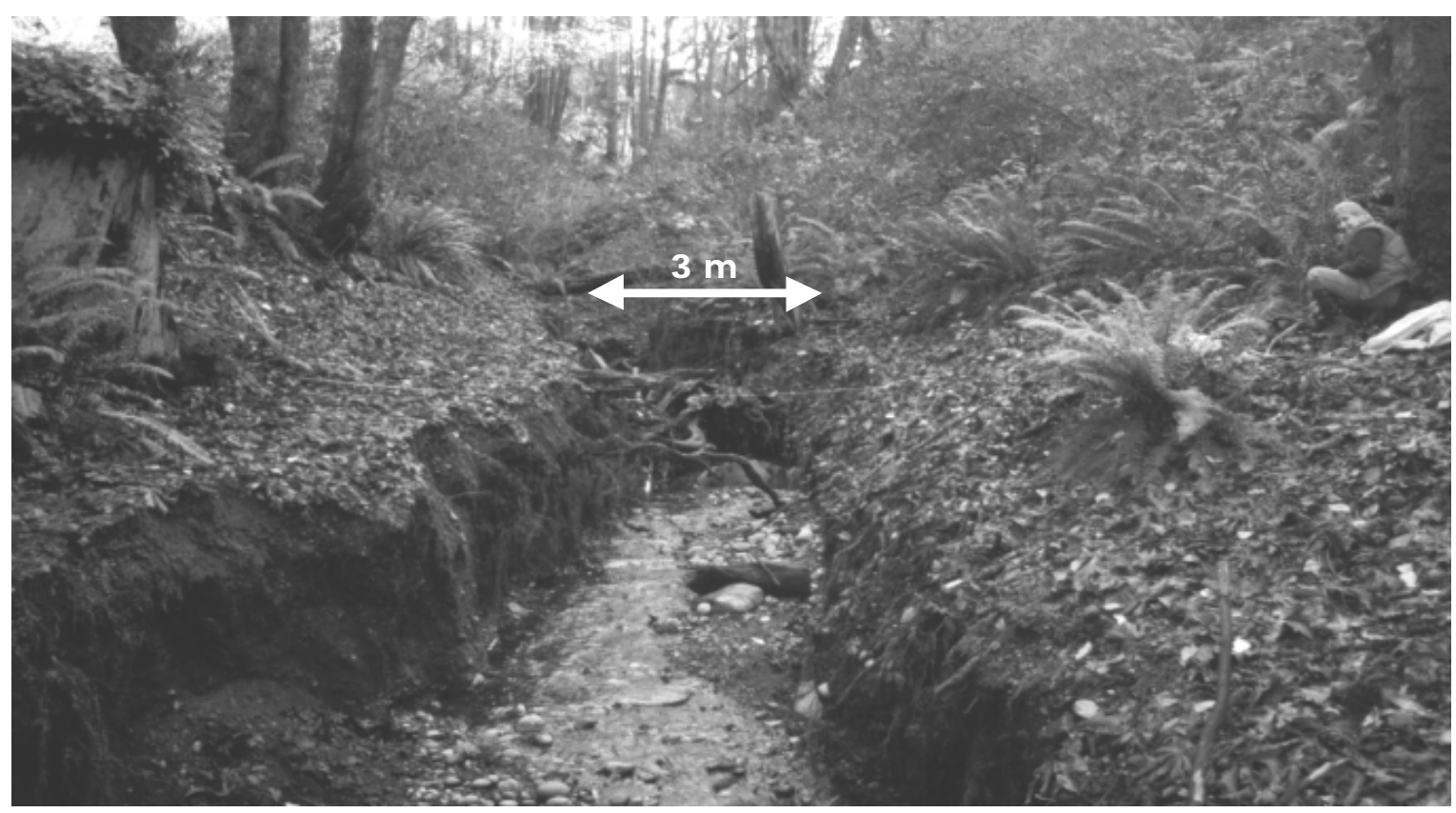

Figure 13. View of the channel of the Easter Lake outlet (Station PS3) in 1986, looking upstream. 
This site displays the interplay of fluvial and hillslope processes and it also demonstrates why cross-sectional measurements can be a very incomplete characterization of stream-channel conditions. Net change at this site has not been dramatic, but bed scour has clearly oscillated with bank failure on a multi-year scale (Figure 14). For example, the steep high right bank remaining after the 1986 storms degraded over the next several years, with progressive bank collapse and channel widening contributing sediment to an aggrading channel bed. Renewed scour during the large flows of January 1990 lowered the bed by nearly 0.5 meters in the active part of the channel, and additional sediment was flushed out through at least 1993. The 1993-1997 interval was a period of substantial channel widening; but in contrast to many other stations during this time, channel deepening did not occur, and in fact aggradation was substantial.

Changes in channel cross section were accompanied by a progressive simplification of in-stream morphological features. Over the 11 years of observations this stream has become more like a drainage ditch, with a marked lack of heterogeneity in either sediment or bedforms. This has not required any direct human intervention; simplification of the channel, with attendant loss of aesthetic and biological benefits, has occurred only through the indirect effects of watershed disturbance.

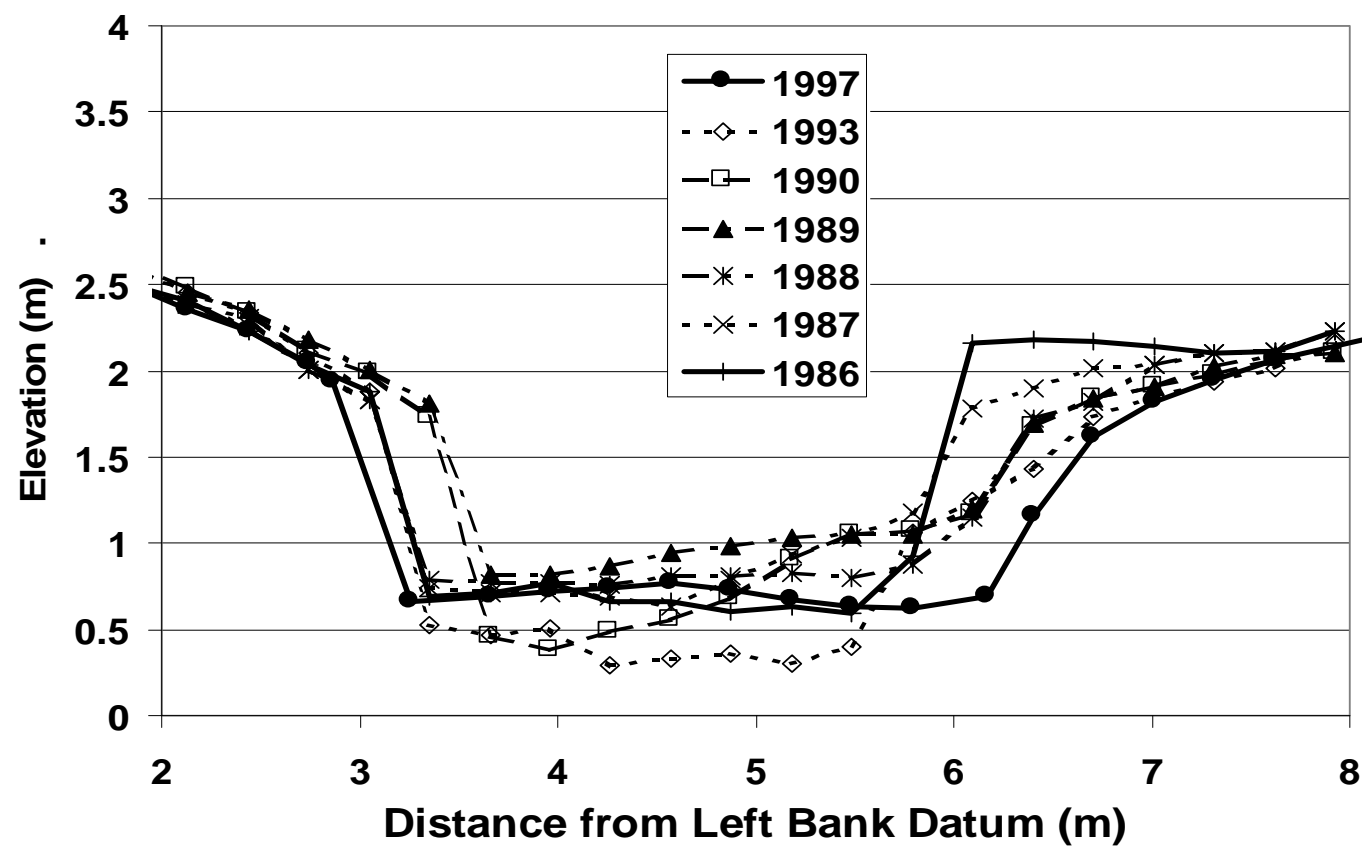

Figure 14. All cross section measurement of Station PS3, showing episodic deepening in 1990 and 1993 but aggradation both before and after. Widening has been progressive but particularly during the interval 1986-1988. 
McAleer Tributary. The third example of a relatively highly impervious, minimally changing channel is a small stream which, for a 200 -m-reach, is surrounded by a surprisingly intact riparian buffer and wetland system. It is isolated from most human traffic by private property and distance from the adjacent county road. This part of the valley has been eroded into resistant silt and clay deposits, which are nowhere visible in the stream bed itself but do lie within a few decimeters of the ground surface and which contribute to the generally silty cohesive banks.

Systematic change at this station over the past decade has been minimal (Figure 15). The channel has aggraded slightly, and the channel banks have become more rounded and have retreated a few tenths of a meter. The clearest interval of change was between 1990 and 1993, when two threads of the flow evolved into a more broadly flowing single channel. Some textural changes in the bed sediment have been noticed over the years, with areas of gravel riffle in one visit becoming patches of silty sand in the next, but no long-term trends in these changes are evident.

Pepper Creek. In contrast to the modest changes observed at the previous stations, this site has shown tremendously variable conditions (Figure 16). It collects runoff from a watershed in the very earliest stages of urbanization; the major hydrologic changes have been related to channelization and road-ditch interception of shallow subsurface flow [Burges et al., 1989], whereas the total fraction of contributing imperviousness is still quite low. The channel is extremely well protected from direct human intrusion, lying several hundred (very brushy) meters from the nearest structure or public road and entirely on private property. It is eroded into sandy valley-bottom deposits, delivered by episodic landslides from the surrounding hillsides and locally reworked by past fluvial action.

The likely magnitude of channel changes was first suggested by extensive deposition on the downstream alluvial fan of the stream, beginning in about 1980 and coincident with the first extensive road construction and forest removal in recent history. Following first measurements in 1986, two episodes of significant erosion were evident: 1986-1987 and 19891990. Channel readjustment, but little net erosion/deposition, occurred in 1987-1988. Near-static conditions persisted during the low-rainfall year of 1989. Substantial erosion continued following 1993, but landsliding off the hillside above the right bank, probably in 1996, completely obliterated the measurement station.

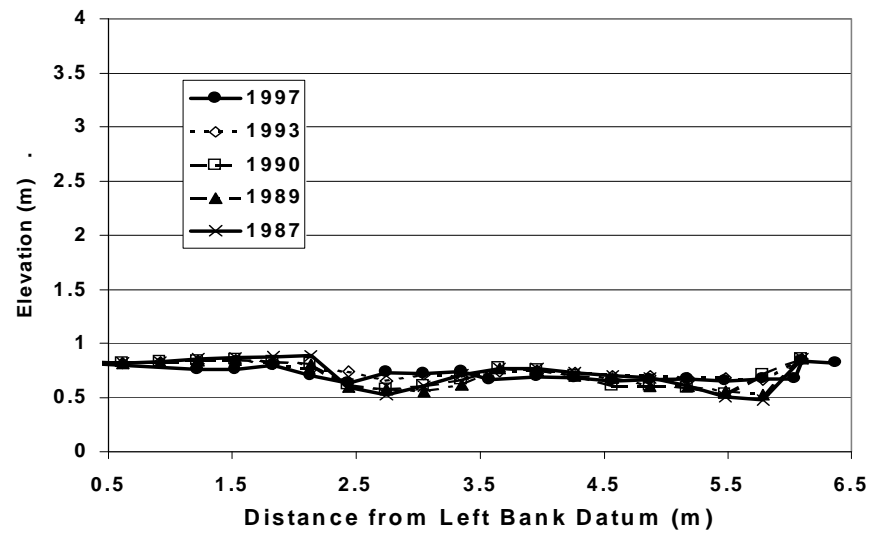

Figure 15. All cross section measurement of Station C2, one of the three sites underlain by cohesive deposits and showing almost no change 1987-1997.

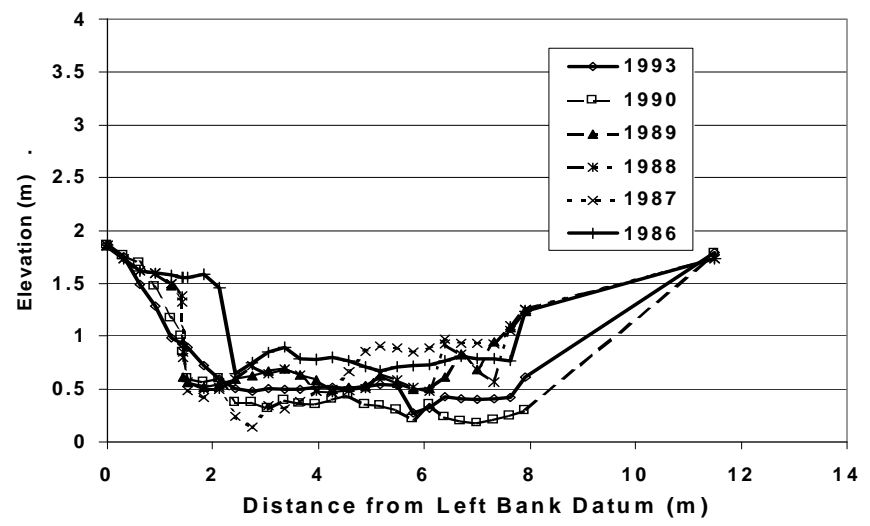

Figure 16. All cross section measurement of Station S3, showing active change in every measurement interval. Vertical exaggeration 2:1 (note expanded horizontal scale). 
Timberline Tributaries. In a topographic and geologic setting remarkably similar to that of Pepper Creek, these smaller tributaries drain adjacent areas generally subjected to intensive urban development. A primary difference between them, however, is that the upland storm-drain system bypasses one (0143F) and discharges into the other (0143G). The stability of 0143F (Figure 17) throughout the measurement period demonstrates that there is nothing inherently unstable about these channels, even where gradients are steep and deposits are erodible. Curiously, the discharge into 0143G was constructed with some advance awareness of the susceptibility of the downstream channel to erosion: rather than simply releasing the runoff from the end of a pipe, the discharges are first attenuated in a detention pond and then released at the head of a swale through a 20-m-long level dispersion pipe. Despite these efforts, first documented in Booth [1989], channel incision of more than one meter occurred in 1989-1990 (Figure 18). In contrast, the station without such flows remained virtually unchanged throughout the period of its measurement.

The respective (in)stabilities of these two channels emphasize a fundamental point about streams in urbanizing environments. Prior to watershed disturbance, "stability" (whether static or dynamic) is the norm. Although gradients are steep and substrate is easily erodible, woody debris and other in-channel roughness elements maintain an overall balance with the tractive stress of the steeply flowing water and the delivery of sediment from farther up in the watershed. If urban development alters any element in this balance, however, the relative stability of the entire system can be lost with rapid and sometimes catastrophic results.

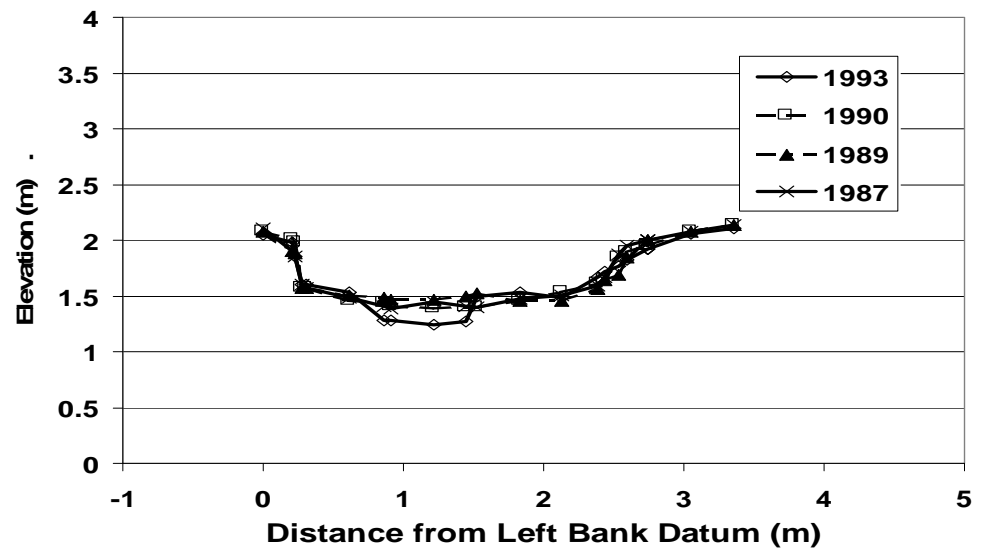

Figure 17. All cross section measurement of Station C9, the Timberline tributary that does not receive any appreciable runoff from the stormwater system of the upslope development.

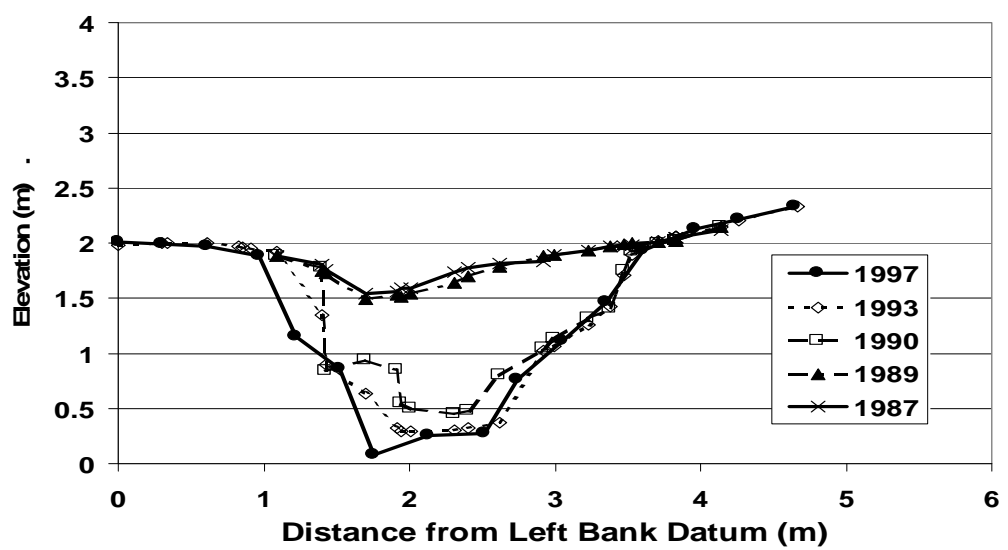

Figure 18. All cross section measurement of Station C8, the Timberline tributary that does receive significant stormwater runoff from the upslope development and which responded with abrupt downcutting in 1989-1990, and further incision by 1997,. 


\section{Rates of Channel Restabilization}

In the final days of 1996, a major storm in the Seattle metropolitan area resulted in the failures of a road embankment and adjacent berm of a regional stormwater detention facility. Massive quantities of water and sediment were flushed down the North Fork and main stem of Boeing Creek, a stream draining several hundred hectares of primarily residential land use, and filled the valley of that channel as deep as $2 \mathrm{~m}$ with deposited sediment. Following this deposition, the channel of Boeing Creek began to reincise immediately, presenting an unexpected opportunity to document the establishment of a channel where watershed land cover was essentially stable (and highly developed) and the sediment to be eroded was very easily transportable by even modest stream discharges. Seven cross sections were established in the 300-m reach between the failed detention pond and Hidden Lake, an artificial pond that marks the downstream end of the alluvial channel on the main stem of Boeing Creek. The normal protocol of annual measurements was replaced by monthly, and in some instances weekly, field visits.

The recovery of the channel of Boeing Creek was anticipated to take a period of some years and to be controlled in part by the reestablishment of floodplain vegetation to help bind and stabilize the very sandy fill that was deposited. Instead, reestablishment of an apparently stable, "equilibrium” channel was very rapid and occurred at most cross sections in a matter of a few months (Figures 19 and 20). The subsequent year's measurements demonstrated that this stability was not an artifact of the termination of rainfall in spring 1997; the 1998 channel, after another winter's high discharges, remained largely unchanged.

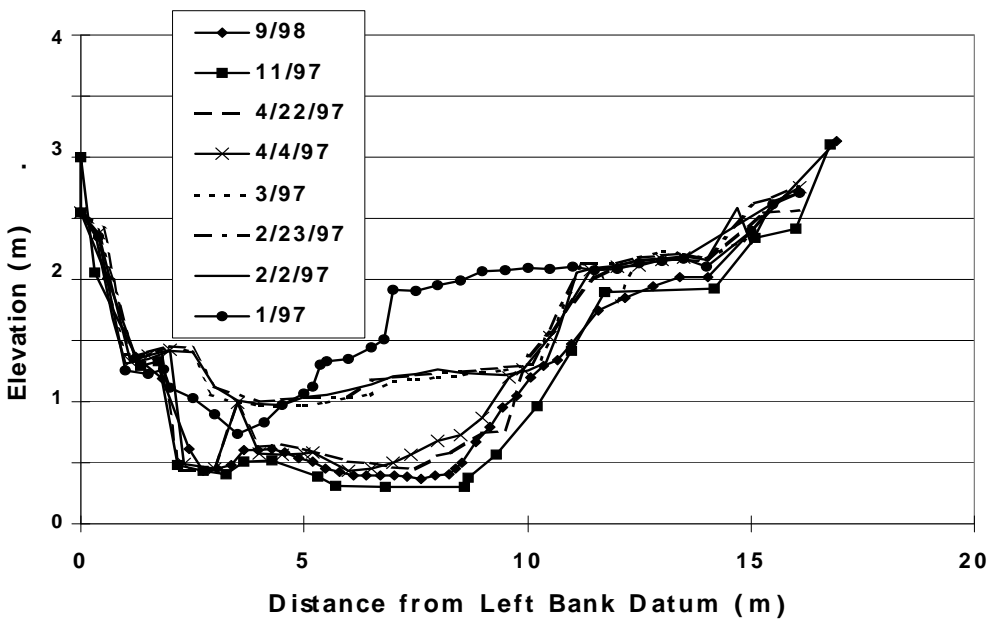

Figure 19. All measurements at Cross Section 4 of Boeing Creek, spanning 20 months since shortly after the site was obliterated by failure of the upstream detention pond embankment. Within weeks the channel achieved a "metastable" form that persisted for about two months (2/97-3/97); following several rainstorms in late March and early April 1997, channel form has remained nearly stable. Vertical exaggeration 2.5:1.

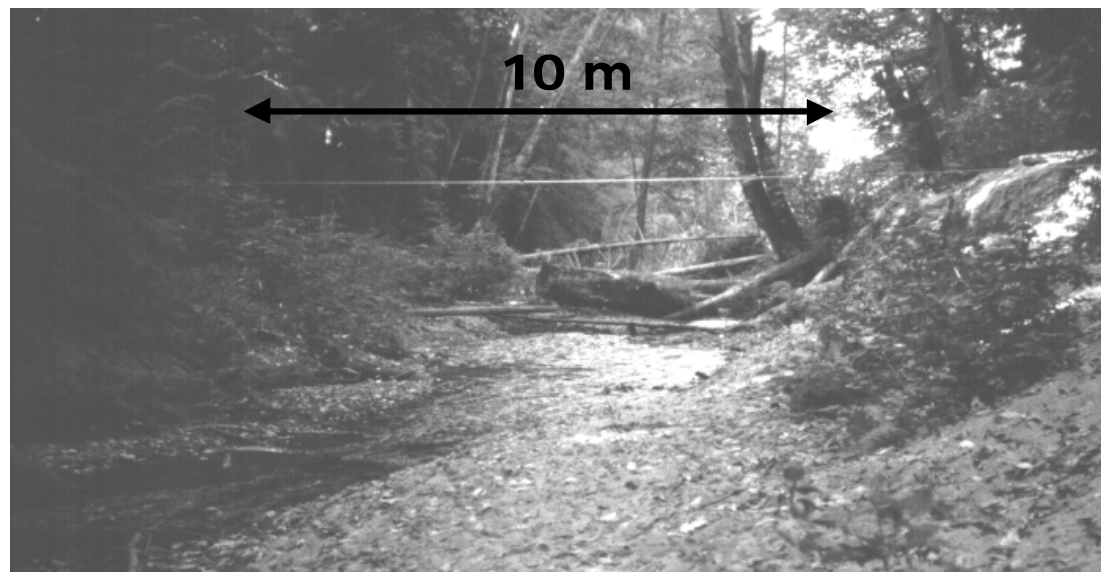

Figure 20. View of the channel of Boeing Creek (Station PS7) at Cross Section 4 on September 9, 1998 (the last measurement plotted in Figure 19), looking downstream. 


\section{Discussion}

The factors anticipated to influence the annual rate of channel change are generally well represented by the results. They include:

- Abundant rainfall,

- Easily erodible substrate, and

- Presence or absence of watershed urbanization.

These factors resist simple quantification, however, because of the tremendous variability imposed by the multiplicity of local geologic conditions, channel type, downstream grade controls (natural or artificial), the location of a chosen site in the context of the upstream channel network, and the variety of development ages and styles (e.g. residential density, or sewered vs. unsewered). Hammer [1972] recognized the last of these complications, and he developed a complex regression equation to express the observed relationship between different development types and channel dimensions. Yet these results are not readily transferred anywhere else, and the ever-changing patterns and styles of development render only the most general conclusions of lasting value.

The population of sample sites was neither varied enough nor large enough to allow a systematic evaluation of every relevant condition. However, several useful observations can be drawn:

1. The average annual rate of change can increase in a single channel by as much as 2 orders of magnitude between dry and wet years (e.g., the winter of 1989-1990, in this sample population); more typically, the greatest interannual change is about 5-fold. Because the study years include some of the largest lowland storms in recent memory as well as several quite unexceptional years, this variability is probably representative of most long-term conditions. In virtually all cases, the rate of channel change returns to nearly equivalent pre-event levels within one measurement interval (typically one or two years).

2. The previously recognized characteristics of erosion-susceptible channels are broadly correct-moderate to steep slopes, susceptible geologic materials, and significant (and recent) upstream development. The unique factors of any given catchment, however, can greatly influence these predictions. No unconsolidated substrate appears immune from change, given sufficiently severe watershed disturbance. The streams draining large basins are more resistant than those draining small ones. Steep slopes in and of themselves are not critical, but they may increase the magnitude of the response to disturbance.

The age of the upstream development appears to be quite significant (as first recognized by Hammer, 1972) but the reason for this influence is enigmatic [see Henshaw, 1999]. In general, channels draining established neighborhoods [C1, C2, PS1, and PS4] show low rates of change. Possible explanations include (1) reequilibration of channel dimensions and sediment size with the increased (but now stable) flow regime; (2) removal of all erodible sediment from the channel perimeter, leaving non-erosive bed and banks; (3) cementation of channel sediments, a ubiquitous condition at these sites; or (4) reestablishment of bank vegetation following initial disruption of the channel by increased flows. Each of these explanations applies to certain sites, although (1) and (2) appear to be the most significant in a majority of cases. The reestablishment of equilibrium, however, does not necessarily coincide with a reestablishment of overall stream function or habitat quality: the channel capable of resisting the frequent, flashy discharges that roll out of an urban catchment is generally inhospitable to most aquatic organisms.

4. Results are most unpredictable in the smallest basins (those of a few tens of hectares). In these basins, even a relatively small amount of development can have significant downstream effects if flow concentration occurs as a result of ditches or road crossings [S4, S5]. These effects, however, are not well represented by traditional methods of characterizing urbanization, such as impervious-area or disturbed-area percentages.

5. Any potential influence of channel slope is not well displayed by this data set (see Figure 8). All channels here have slopes of at least 1.3 percent, so true low-slope channels (also correlating, typically, with larger channels) are not represented. Within this data set, the only apparent relationship is that the very largest changes ( $>0.3 \mathrm{~m} / \mathrm{yr}$ ) appear to require a steep slope (4 percent or greater).

The experiences from this study also suggest several cautionary notes for future long-term channel monitoring. Most importantly, single-site measurements do not reliably characterize the overall status of the channel. Conditions both upstream and downstream of the selected site can be very different from those at the measured station. For example, delivery of sediment from an unstable upstream source can completely obscure the local behavior of the measured section. The headward migration of a downstream knickpoint, one obvious (and common) manifestation of an unstable stream reach [Booth, 1990], can cause dramatic changes in the bed elevation after a long period of apparent channel stability as measured at a single monitoring site.

Furthermore, the "stability" of a channel, as measured by the absence of change at single cross sections, does not necessarily equate with other desirable conditions, such as high-quality aquatic habitat. The converse statement, however, is generally correct: instability does correlate well with low habitat quality. Therefore, evaluating only channel stability 
does not provide unequivocal information on habitat conditions; if that information is needed, additional measurements are required.

\section{SUMMARY}

This study was begun with four objectives: to document rates of channel change, to evaluate the relationship between development intensity and the rate of channel change, to evaluate geologic and topographic controls on channel change, and to determine if predevelopment conditions could be used to predict susceptible reaches. Our results indicate the following conclusions:

1. Rates of vertical channel change vary from below the range of measurement error $(<20$ mm vertical change between visits) to about $1 \mathrm{~m}$ (width-averaged) per year. The median rate for this sample population was $60 \mathrm{~mm}$ per year.

2. Within these lightly to moderately urbanized watersheds, rates of channel change did not correlate with development intensity.

3. The nature of the geologic substrate strongly influenced whether or not significant channel change occurred. Other likely influences included local downstream grade control, riparian vegetation, and the age of the upstream development. Gradient was not a significant factor across the range of channels measured (0.013-0.52), but the importance of local grade controls suggest that low-gradient channels may show lower rates of change for a given level of disturbance and geologic susceptibility.

4. Channels with the greatest susceptibility share the following characteristics, which could be used to reduce the consequences of future urban development on natural stream systems:

- Erosion-susceptible geologic substrate

- Moderate to high gradient

- Absence of natural or artificial grade controls

- Water inputs via predominantly subsurface discharge, likely to be converted to surface (point) discharge in the post-development condition.

\section{MANAGEMENT IMPLICATIONS}

These results imply several consequences for watershed management. First, urban development is an obvious force in channel change, yet not all channels respond equivalently. The locations of potential susceptibility can be determined well in advance, at least in the Puget Lowlands of Washington, based on geologic conditions. Finally, channel changes, if and when they do occur, can happen so rapidly after development begins that remediation, to be effective, must occur prior to development.

The results of this study also suggest that channel changes are very responsive to varying rainfall. This source of variability is obviously beyond the ability of surface-water or land-development agencies to control, yet its effects can be as significant as those of urban development. The most extreme effects of high rainfall are felt in the urbanized channels, and so one result of large storms is to amplify the differential response of developed and undeveloped watersheds. This imposes a challenging task for watershed managers: during low-rainfall years, any "warning” of impending channelerosion disaster is muted, along with the public's concern for such issues. When a large storm arrives, however, the magnitude of channel change in urbanizing watersheds can cause significant damage, and its consequences invariably surprise almost everyone.

Acknowledgements. We are indebted to the associates and assistants who have helped with project design, site selection, and field assistance over the years, particularly Laura Casey, Kelin Whipple, Adelaide Johnson, John Buffington, Fred Bentler, Arny Stonkus, Karen Comings, and Marit Larson. Joan Blainey was instrumental in establishing the initial sites and making the first-year measurements on Boeing Creek. Partial support for the successful conclusion of this project was provided by the U. S. Environmental Protection Agency’s Waters and Watersheds Program Grant no. R825284-01-0, and the Center for Urban Water Resources Management at the University of Washington. The manuscript was greatly improved from careful reviews by Ellen Wohl, Jim Pizzutto, and Kelin Whipple. 


\section{REFERENCES}

Armstrong, J. E., Crandell, D. R., Easterbrook, D. J., and Noble, J. B., Late Pleistocene stratigraphy and chronology in southwestern British Columbia and northwestern Washington, Geological Society of America Bulletin, 76, 321-330, 1965.

Arnold, C. L., Boison, P. J., and Patton, P. C., Sawmill Brook, an example of rapid geomorphic change related to urbanization, Journal of Geology, 90, 155-166, 1982.

Bird, J. F., Channel incision at Eaglehawk Creek, Gippsland, Victoria, Australia, Proceedings of the Royal Society of Victoria, 94, 1122, 1982.

Booth, D. B., Runoff and stream-channel changes following urbanization in King County, Washington, in Engineering Geology in Washington, Vol. II, edited by R. Gallster, Washington Division of Geology and Earth Resources Bulletin 78, 639-650, 1989.

Booth, D. B., Stream-channel incision following drainage-basin urbanization, Water Resources Bulletin, 26, 407-417, 1990.

Booth, D. B., Urbanization and the Natural Drainage System--Impacts, Solutions, and Prognoses, Northwest Environmental Journal, 7 , 93-118, 1991.

Booth, D. B., and Jackson, C. R., Urbanization of aquatic systems - degradation thresholds, stormwater detention, and limits of mitigation, Journal of the American Water Resources Association, 33, 1077-1090, 1997.

Burges, S. J., Stoker, B. A., Wigmosta, M. S., and Moeller, R. A., Hydrological information and analyses required for mitigating hydrologic effects of urbanization, Water Resources Series Technical Report 117, University of Washington, Department of Civil Engineering, Seattle, 1989.

Dinicola, R. S., Characterization and simulation of rainfall-runoff relations for headwater basins in western King and Snohomish Counties, Washington state, U. S. Geological Survey Water-Resources Investigation Report 89-4052, 1990.

Douglas, I., Urban sedimentology, Progress in Physical Geography, 9, 255-280, 1985.

Dunne, T., and Leopold, L. B., Water in Environmental Planning, W. H. Freeman and Company, New York, 1978.

Ebisemiju, F. S., The response of headwater stream channels to urbanization in the humid tropics, Hydrological Processes, 3, 237-253, 1989a.

Ebisemiju, F. S., Patterns of stream channel response to urbanization in the humid tropics and their implications for urban land use planning: a case study from southwestern Nigeria, Applied Geography, 9, 273-286, 1989b.

Graf, W. L., The impact of suburbanization on fluvial geomorphology, Water Resources Research, 11, 690-692, 1975.

Gregory, K. J., Davis, R. J., and Downs, P. W., Identification of river channel change due to urbanization, Applied Geography, 12, 299318, 1992.

Hammer, T. R., Stream and channel enlargement due to urbanization, Water Resources Research, 8, 1530-1540, 1972.

Henshaw, P. C., Restabilization of stream channels in urban watersheds, American Water Resources Association, Annual Water Resources Conference on "Watershed Management to Protect Declining Species," Seattle, WA, 1999.

Hollis, G. E., and Luckett, J. K., The response of natural river channels to urbanization: two case studies from southeast England, Journal of Hydrology, 30, 351-363, 1976.

King County, 1990, Hylebos Creek and Lower Puget Sound Basins Current and Future Conditions Report, Department of Public Works, Surface Water Management Division, Seattle, WA, 4 sections.

Kondolf, G. M., Geomorphological stream channel classification in aquatic habitat restoration: uses and limitations, Aquatic Conservation: Marine and Freshwater Ecosystems, 5, 127-141, 1995.

Leopold, L. B., River channel change with time—an example, Geological Society of America Bulletin, 84, 1845-1860, 1973.

Leopold, L. B., Wolman, M. G., and Miller, J. P., Fluvial Processes in Geomorphology, W. H. Freeman and Co., San Francisco, 1964.

Miller, J. F., Frederick, R. H., and Tracey, R. J., Precipitation-frequency atlas of the western United States, U. S. Department of Commerce, Volume XI-Washington, Washington, DC, 1973.

Montgomery, D. R., and Buffington, J. M., Channel reach morphology in mountain drainage basins, Geological Society of America Bulletin, 109, 596-611, 1997.

Morisawa, M., and LaFlure, E., 1982, Hydraulic geometry, stream equilibrium and urbanization, in Adjustments of the Fluvial System, edited by D. D. Rhodes and G. P. Williams, Allen and Unwin, London, 333-350.

Moscrip, A. L., and Montgomery, D. R., Urbanization, flood frequency, and salmon abundance in Puget Lowland streams, Journal of the American Water Resources Association, 33, 1289-1297, 1997.

Mosley, M. P., The classification and characterization of rivers, in River Channels: Environment and Process, edited by K. Richards, Blackwell, Oxford, 294-320, 1987.

Nanson, G. C., and Young, R., W., Downstream reduction of rural channel size with contrasting urban effects in small coastal streams of southeastern Australia, Journal of Hydrology, 52, 239-255, 1981.

Neller, R. J., A comparison of channel erosion in small urban and rural catchments, Armidale, New South Wales, Earth Surface Processes and Landforms, 13, 1-7, 1988.

Odemerho, F. O., Limited downstream response of stream channel size to urbanization in a humid tropical basin, Professional Geographer, 44, 332-339, 1992.

Park, C. C., Channel cross-sectional change, in Changing River Channels, edited by A. Gurnell and G. Petts, John Wiley and Sons, Chichester, 117-145, 1997.

Rosgen, D. L., A classification of natural rivers, Catena, 22, 169-199, 1994.

Simon, A., A model of channel response in disturbed alluvial channels, Earth Surface Processes and Landforms, 14, 11-26, 1989.

Tinkler, K. J., and Parish, J., Recent adjustments to the long profile of Cooksville Creek, and urbanized bedrock channel in Mississauga, Ontario, in Rivers Over Rock: Fluvial Processes in Bedrock Channels, edited by K. J. Tinkler and E. E. Wohl, American Geophysical 
Union, Monograph 107, Washington, DC, 167-187, 1998.

Whitlow, J. R., and Gregory, K. J., Changes in urban stream channels in Zimbabwe, Regulated Rivers: Research and Management, 4, 27-42, 1989.

Wolman, M. G., A cycle of sedimentation and erosion in urban river channels, Geografiska Annaler, 49A, 385-395, 1967. 